\title{
Always, There Is The Night and Other Poems
}

Alex Fewings, University of Warwick

\section{Abstract}

Always, There Is the Night is certainly the one of my poems most closelyrelated to Crosses to Cullens. It deals with the reinvention of ideas and themes across time through the lens of the vampire. However, where the article functions to explore the ideas of sexuality and romance in relation to the vampire, Always is much more a commentary on capitalism, avarice and the physical and spiritual fallout of their running loose. In this, I see it as one in a long line of such comparisons, leading all the way back to Marx's description of capital as 'dead labour, that, vampire-like, only lives by sucking living labour’ (Marx, 1887: 163).

The Run, by contrast, is less closely-connected. Instead of giving light to a facet of the vampire that I could not include in the paper, it represents my attempt to capture a sense of the sublime awe of nature on which Romantic literature (and the Gothic which grew out of it) was founded. The poem describes a natural force which the people contrasted against it cannot overcome, then 'pans up' to a greater force only a few metres away.

Finally, Amphora is a direct way of addressing the sexual elements of the vampire mythos. Though it does not deal directly with vampires, and owes much more to Greek myth and its reinventions, the poem is an attempt to grasp the kind of 'feverish' desire for another that often characterises both vampires' frequent attitudes towards their prey, and the allure of the creatures themselves towards others. However, I alloyed sexual desire with a more emotional sense of intimacy.

\section{Always, There Is the Night}

Always, there is the night.

A hand, an eye, here, there, a glint on nails, on teeth 
high, high:

The billboard their

white-toothed epitaph,

fading on their curves

their black suit,

their lace dress

rot-eaten.

Always, there is the night.

A cap, a face, palefish smog-swimmer

beneath the gaslight stars, their fading shimmer.

One hand

around a glass neck, the other chewed, gnashed and steel-tooth torn away, fired.

Always, there is the night.

A ship, a sail, the bobbing werelight, the heaving deep, the white-lined shore. The thirstless land wetted red.

The scar-lines laid for howling engines, their gunshot laugh. The bison lie, gutted.

Always, there is the night.

\section{Poetry commentary}

This poem was based on the concept of the vampire, using the eternal life and thirst of that figure to comment upon the perennial parasitism of a 
capitalist system. Each stanza represents a historical phase as one looks back upon this process, from the first, which depicts modern times in terms of commodification of appearance, rotting from within, to the second - the industrial revolution and its brutal factories - to the third, which depicts a snapshot of colonialism.

\section{The Run}

I went down to the Run on Sunday, the gargling mouth of the tide, unsatisfied with the river or the sea alone.

The sand is a pod of whales, rising smooth islands in the stream, stoneless, bare, the sun slanting low to gild the pools of abandoned brine and skip over the crests of the rapid ripples.

Beachgoers wander here becoated, tall shore birds going this way and that, startling at the dogs that run between their feet, remembering only barely the beast that stalks them in their too-close passages.

I saw three, mother-child-child, who made to wade the Run, their rubber-yellow legs like storks, too wide, too tall.

I saw it take a hold of them, tug them out, the greedy thing, against the mother's hand, the child like a windsock in the current. They turned back, and I saw that that was not the Run only a second channel to the Channel sea.

And I turned my eye to greater course, and saw the rocks there worn. 


\section{Poetry commentary}

This poem was composed after visiting the Run at Avon Beach near Christchurch. The Run is a channel from Mudeford Bay to the sea, where the tide runs powerfully. While I was there, I saw a woman and what I presumed to be her two children attempting to wade across a side-channel, but turning back, and the contrast between them and the power both of the side-channel and the Run itself struck me with a strange kind of awe I attempted to capture here.

\section{Amphora}

You are terracotta, your skin here and here and here, moves out and in, beneath my hand, the curve of your well-worn hip, its sun-brown smooth ceramic pale-chipped where that stone caught you on Pelion.

My finger is another apology laid there atop the rest though you have never held me to account. I am not used to guilt, but for this I feel it, no matter how many times your laughing lilt lends assurance I need not.

Need, though, I know too well; your mortal clay and the red wine below that cools my hands, held against your flesh feverish with divinity, hoping you might 
bless another day

and pour out the sun

for me to drink.

\section{Poetry commentary}

This poem is based upon the relationship of Achilles and Patroclus as depicted in Homer's Iliad, and in Madeline Miller's novel The Song of Achilles. The novel focuses on the way in which Achilles is torn between glorious divinity and mortal happiness. I tried to write a poem from his perspective, emphasising his desire for and devotion to his lover. It was also an experiment of attempting to depict a sexual act in terms less of physicality and more of emotional intimacy and profundity of feeling what it means rather than what it is.

\section{Pygmalion}

I see your marks here, signs of the chisel

you chose; that old bronze thing re-sheathed in steel, and then again in polymer, gunsmoke wafting from the blows. You picked ivory as well, gave the hunter obols to put bullet to tomorrow for your image, your hungry, hideous desire: skin white, eyes white, teeth white, white hands, white blood, waist anorexic-thin, tapering out, down to the serpent-flesh, many-branched, twisting back around, idiot ouroboros, to eat itself, your desire made flesh in its perfect, sterile self-consumption.

Oh, you wail and cry, you give us the dust of your carving and say you make it right. You make us worms, gnawing at the roots of the world, you and your vile Galatea.

\section{Poetry commentary}

Pygmalion draws on the imagery of the figure depicted in Ovid's Metamorphoses, but is more concerned with the hypocrisy of 
modern powerful figures blaming individuals or others for the ecological devastation and economic inequality created by the system they uphold and benefitted from, and for the cyclical violence that system requires to be sustained.

\section{References}

Marx, K. (1887) Capital. Progress Publishers, Moscow.

To cite this paper please use the following details: Fewings, A. (2022), 'Always, There Is The Night and Other Poems', Reinvention: an International Journal of Undergraduate Research, Special Issue | Reeling and Writhing: Intertextuality and Myth, https://reinventionjournal.org/article/view/984. Date accessed [insert date]. If you cite this article or use it in any teaching or other related activities please let us know by e-mailing us at Reinventionjournal@warwick.ac.uk. 